\title{
Recent pathotype development of New Zealand cereal rust populations
}

\author{
Rachael M. Warren ${ }^{1}$, William Cuddy ${ }^{2}$, Robert F. Park ${ }^{3}$, Rob Craigie ${ }^{4}$ and \\ Soonie F. Chng ${ }^{1, \star}$ \\ ${ }^{1}$ The New Zealand Institute for Plant \& Food Research Limited, Lincoln 7608, New Zealand \\ ${ }^{2}$ NSW Department of Primary Industries, Locked Bag 21, Orange NSW 2800, Australia \\ ${ }^{3}$ Australian Cereal Rust Control Programme, University of Sydney, NSW 2600, Australia \\ ${ }^{4}$ The Foundation for Arable Research, PO Box 23133, Hornby 8441, New Zealand \\ *Corresponding author: Soonie.chng@plantandfood.co.nz
}

\begin{abstract}
Rust diseases are serious threats to New Zealand cereal crops. Beside the use of fungicides, resistant varieties are an important option for managing these diseases. Changes in rust pathotypes commonly occur due to mutations in existing populations or exotic incursions. Information on these changes is the basis of gene-based disease management. Rust-infected leaves were collected from cereal crops from 2012 to 2015 . The pathotypes of these and some historic samples were determined in glasshouse studies, using specific differential host sets. Eight pathotypes of Puccinia triticina (Pt, causal agent of wheat leaf rust), five of $P$. striiformis f. sp. tritici (Pst, causal agent of wheat stripe rust) and two of $P$. hordei ( $P h$, causal agent of barley leaf rust) were identified. The Pst 'WA' pathotype was most frequently found. Wheat varieties 'Empress' and 'Torch', previously resistant to $P t$, were found to be susceptible to leaf rust for the first time. The 'WA' pathotype of Pst is likely to have arrived in New Zealand from Australia, and is now widespread. The two Pt pathotypes could have overcome resistance gene Lr24 in 'Empress' and 'Torch'.
\end{abstract}

Keywords: wheat stripe rust, Puccinia striiformis f. sp. tritici, wheat leaf rust, Puccinia triticina, barley leaf rust, Puccinia hordei, resistance, disease, Lr24 gene

\section{INTRODUCTION}

Rust diseases are serious threats to the profitability of cereal growing in New Zealand. The common rust diseases present in New Zealand include wheat stripe rust (caused by Puccinia striiformis f. sp. tritici, Pst), wheat leaf rust (caused by Puccinia triticina, $P t$ ) and barley leaf rust (caused by Puccinia hordei, $P h$ ). Reported yield losses are between 20 and $84 \%$ from wheat stripe rust (Doling \& Doodson 1968; Beresford 1982; Murray et al. 1995) and between 10 and 70\% from wheat leaf rust (Samborski 1985; HuertaEspino et al. 2011) in susceptible cultivars.

In New Zealand, cereal rust diseases are controlled by seed dressing with appropriate fungicides (limited control), broad-spectrum foliar fungicide applications, and more commonly, by growing rust-resistant varieties (Cromey 1992; Braithwaite et al. 1998). Breeding and growing resistant cereal varieties is the most sustainable long-term solution to combating rust diseases. Despite advances in breeding technologies, rusts continue to threaten cereal production, due to the development of new pathotypes that differ in ability to overcome resistance genes. Pathotype variants commonly occur, arising either by step-wise mutations within local rust populations, or less commonly by the introduction of new pathotypes from outside the country.

Surveys to monitor evolving rust populations are crucial for gene-based disease control 
strategies. Knowledge of currently effective rust resistance genes aids resistance breeding programmes, and enables growers to select resistant commercial varieties. Historically, annual surveys of New Zealand cereal rust pathotypes (initiated in 1971) were carried out by the Plant Breeding Institute (PBI, University of Sydney), where samples were sent from New Zealand and tested (Park \& Wellings 1992). However, these surveys ceased in 2002 due to changed Australian quarantine regulations. The 'WA' Pst pathotype was first recorded in Western Australia in 2002 (Wellings et al. 2003), and was found in the eastern Australian states the following year. This pathotype is notable for virulence to the host resistance genes $\mathrm{Yr} 8$ and Yr9 (Wellings et al. 2003). Limited pathotyping of New Zealand stripe rust samples conducted between 2002 and 2012 identified the 'WA' pathotype as present in New Zealand from 2012 (Cromey 2013).

The collective information derived from past pathotyping studies has emphasised the importance of maintaining this type of surveillance, and highlights the need to manage information on current rust pathotypes in preparation for the arrival of new pathotypes in the Australasian region. This paper describes recent changes in the pathotypes of New Zealand populations of $P s t, P t$, and $P h$ from a survey collaboratively initiated by The New Zealand Institute of Plant \& Food Research (PFR), the Foundation for Arable Research (FAR), the University of Sydney, the NSW Department of Primary Industries (DPI) and the Australian Plant Biosecurity Cooperative Research Centre (PBCRC).

\section{MATERIALS AND METHODS}

\section{Rust collections}

Samples of rust from infected wheat, barley, or rye were collected from commercial crops, roadsides, and experimental trials throughout Canterbury, Southland, and ManawatuWanganui, the main cereal-growing regions of New Zealand between 2012 and 2015. Several previously collected rust samples were also included. Leaf samples transported in paper bags, before being were placed in 100\% humidity at $4^{\circ} \mathrm{C}$, and urediniospores were collected over a $72-\mathrm{h}$ period. These were dried over silica gel and stored at $-80^{\circ} \mathrm{C}$ in sealed foil packets until required. In some cases, infected leaf samples were used directly to inoculate plants.

\section{Glasshouse inoculation procedures}

Seedlings raised in $11 \times 11 \mathrm{~cm}$ pots (seven to 10 seedlings of four or five differential wheat or barley varieties; Tables 1-3) were inoculated at the two-leaf stage by atomisation using approx. $1 \mathrm{mg} \mathrm{mL}^{-1}$ of urediniospores suspended in light mineral oil (Pegasol, 3440 special, Mobil Oil). Plants were incubated in high humidity in the dark for $18-24 \mathrm{~h}$ at $11^{\circ} \mathrm{C}$ (Pst inoculations), or $21^{\circ} \mathrm{C}(P t$ and $P h)$. Inoculated plants were maintained on glasshouse benches at $18^{\circ} \mathrm{C}(P s t)$, or $21-23^{\circ} \mathrm{C}(P t$ and $P h)$, with $16 / 8 \mathrm{~h} \mathrm{light/dark}$ daily cycles.

\section{Recording seedling responses}

Seedling responses were assessed on an infection type (IT) scale, using categories of fleck (;), 1-4 (increasing severity), chlorosis (C), necrosis $(\mathrm{N})$, and heterogeneousness $(\mathrm{X})$, with the use of - or + to indicate, respectively, less or greater compatibility. Infection types $3+$ and 4 were considered compatible (i.e. virulent pathogen/ susceptible host). All other infection types, including $\mathrm{X}$, were considered incompatible.

\section{Pathotype designations}

The pathotype(s) present in each rust sample were identified based on the reactions of the differential varieties at 10 to 16 days post inoculation. Differentials and corresponding octal or decanery values are given in Tables 1-3. The differential sets were specific to each pathogen, and included host varieties which carry known resistance genes. The system used for characterising each pathotype was that described by McIntosh et al. (1995), with designations determined by adding octal or decanery values that correspond to each differential to which a given isolate was virulent. 
Table 1 Wheat genotypes used to differentiate pathotypes of Puccinia striiformis f. sp. tritici, causing stripe rust of wheat.

\begin{tabular}{|c|c|c|}
\hline Line & Resistance gene & Decanery value \\
\hline \multicolumn{3}{|l|}{ International series } \\
\hline Chinese 166 & $\operatorname{Yr} 1$ & 1 \\
\hline Lee & $\operatorname{Yr} 7$ & 2 \\
\hline Heines Kolben & Yr6, Yr2 & 4 \\
\hline Vilmorin 27 & Yr3 & 8 \\
\hline Moro & Yr10 & 16 \\
\hline Strubes Dickkopf & $\operatorname{Yr} 2, \operatorname{Yr} 25$ & 32 \\
\hline Suwon 92/Omar & $Y r S 92 / O$ & 64 \\
\hline Clement & $\operatorname{Yr} 9, \operatorname{Yr} 2$ & 128 \\
\hline Triticum Spelta & Yr5 & 256 \\
\hline \multicolumn{3}{|l|}{ European series } \\
\hline Hybrid 46 & Yr4 & E1 \\
\hline Reichersberg 42 & Yr7 & E2 \\
\hline Heines Peko & Yr6, Yr2, Yr25 & $\mathrm{E} 4$ \\
\hline Nord Desprez & Yr3, Yr4 & E8 \\
\hline Compair & Yr8 & E16 \\
\hline Carstens V & Yr32, Yr25 & E32 \\
\hline Spaldings Prolific & $Y r S p$ & E64 \\
\hline Heines VII & Yr2, Yr25 & E128 \\
\hline \multicolumn{3}{|l|}{ Australian series } \\
\hline Avocet R & $\operatorname{Yr} A$ & \\
\hline Kalyansona & $Y r 2$ & \\
\hline Trident & $\operatorname{Yr} 17$ & \\
\hline Yr $15 / 6^{*}$ AvS & $\operatorname{Yr} 15$ & \\
\hline Hugenoot & $\operatorname{Yr} 25$ & \\
\hline Selkirk & $\operatorname{Yr} 27$ & \\
\hline Yr 9 NILS & $\operatorname{Yr} 9$ & \\
\hline Avocet S & $\operatorname{Yr} A$ & \\
\hline Gregory & $\operatorname{Yr} 33$ & \\
\hline Ellison & $\operatorname{Yr} 17$ & \\
\hline \multicolumn{3}{|l|}{ Claire } \\
\hline Breakwell & YrJ & \\
\hline Morocco & Susceptible & \\
\hline Binnu & Yr17 & \\
\hline Clipper Sahara & & \\
\hline
\end{tabular}


Table 2 Wheat genotypes used to differentiate pathotypes of Puccinia triticina, causing leaf rust of wheat.

\begin{tabular}{|c|c|c|}
\hline Line & Resistance gene & Octal value \\
\hline \multicolumn{3}{|l|}{ International series } \\
\hline Tarsa & Lr1 & \\
\hline Webster & $\operatorname{Lr} 2 a$ & \\
\hline Mediterranean & $\operatorname{Lr} 2 a, \operatorname{Lr} 3 a$ & \\
\hline Democrat & $\operatorname{Lr} 3 a$ & \\
\hline \multicolumn{3}{|l|}{ Australian series } \\
\hline Thew & $\operatorname{Lr} 20$ & 1 \\
\hline Gaza & $\operatorname{Lr} 23$ & 2 \\
\hline Spica & $\operatorname{Lr} 14 a$ & 3 \\
\hline K1483 & $\operatorname{Lr} 15$ & 4 \\
\hline Klein Titan & $L r 3 k a$ & 5 \\
\hline Gatcher & $\operatorname{Lr} 27+\operatorname{Lr} 31$ & 6 \\
\hline Songlen & $\operatorname{Lr} 17 a$ & 7 \\
\hline $\mathrm{CS} 2 \mathrm{~A} / 2 \mathrm{M}$ & $\operatorname{Lr} 28$ & 8 \\
\hline Mildress & Lr26 & 9 \\
\hline Egret & $\operatorname{Lr} 13$ & 10 \\
\hline Exchange & Lr16 & 11 \\
\hline Harrier & $\operatorname{Lr} 17 b$ & 12 \\
\hline Agent & $\operatorname{Lr} 24$ & 13 \\
\hline \multicolumn{3}{|c|}{ Additional genotypes } \\
\hline Sunlin & $\operatorname{Lr} 37$ & \\
\hline Sun $6 \mathrm{~B}$ & $\operatorname{Lr} 1, \operatorname{Lr} 3 a, \operatorname{Lr} 27,+\operatorname{Lr} 31$ & \\
\hline Naparoo & $\operatorname{Lr} 13, \operatorname{Lr} 24$ & \\
\hline Agatha & $\operatorname{Lr} 19$ & \\
\hline Norka & $\operatorname{Lr} 1, \operatorname{Lr} 20$ & \\
\hline Mentana & Lr3bg & \\
\hline Morocco & Susceptible & \\
\hline
\end{tabular}


Table 3 Barley genotypes used to differentiate pathotypes of Puccinia hordei, causing leaf rust of barley.

\begin{tabular}{|c|c|c|}
\hline Line & Resistance gene & Octal value \\
\hline Gus & Susceptible & \\
\hline Sudan & $R p h 1$ & 1 \\
\hline Berg & Rph1 & \\
\hline Peruvian & Rph2 & 2 \\
\hline \multicolumn{3}{|l|}{ Gatam } \\
\hline Reka I & $R p h 2+19$ & \\
\hline Ricardo & Rph $2+21$ & \\
\hline Estate & Rph3 & 4 \\
\hline Gold & Rph4 & 10 \\
\hline Rph13 & Rph13 & \\
\hline Quinn & $R p h 2+5$ & \\
\hline Magnif 104 & Rph5 & 20 \\
\hline Bolivia & Rph $2+6$ & 40 \\
\hline C. Capa & Rph7 & 100 \\
\hline Rph14 & Rph14 & \\
\hline Egypt 4 & Rph8 & 200 \\
\hline Abyssinian & Rph9 & 400 \\
\hline Rph10 & Rph10 & 1000 \\
\hline Rph11 & Rph11 & 2000 \\
\hline Triumph & Rph12 & 4000 \\
\hline Prior & $R p h P+C$ & \\
\hline Cutter & Rph19 & \\
\hline Q21861 & $R p h Q$ & \\
\hline Cantala & $R p h C$ & \\
\hline B37 & RphB37 & \\
\hline Bowman+Rph15 & Rph15 & \\
\hline Pickering 1 & Rph17 & \\
\hline \multicolumn{3}{|l|}{ Pickering 3} \\
\hline Pickering 4 & Rph18 & \\
\hline Pickering 8 & & \\
\hline
\end{tabular}

\section{RESULTS}

\section{Stripe rust of wheat}

In total, 28 Pst samples were inoculated onto differential sets. Eight were samples collected before 2012, which had not previously been pathotyped. Overall, 11 Pst pathotypes, belonging to three distinct groups were identified. Details of the pathotypes, their detection status in New
Zealand and Australia, and their virulence to different resistance genes are listed in Table 4. A group of six pathotypes were identified in the pre2012 samples (Table 4), which were previously reported as present in New Zealand (Wellings \& McIntosh 1990; Cromey 1992; Park \& Wellings 1992). 
Table 4 Pathotypes of Puccinia striiformis f. sp. tritici (wheat stripe rust) identified in the present survey, their occurrence in New Zealand and Australia, and their virulence status to different resistance genes.

\begin{tabular}{|c|c|c|c|c|}
\hline Pathotype & $\begin{array}{c}\text { Year of first } \\
\text { New Zealand } \\
\text { detection }\end{array}$ & $\begin{array}{l}\text { Year of first } \\
\text { Australian } \\
\text { detection }\end{array}$ & $\begin{array}{l}\text { Number } \\
\text { of samples } \\
\text { (year of } \\
\text { collection) }\end{array}$ & Virulence to resistance genes \\
\hline \multicolumn{5}{|l|}{ Original pathotype } \\
\hline $104 \mathrm{E} 137 \mathrm{~A}+$ & 1980 & 1979 & $\begin{array}{c}1 \\
(1993)\end{array}$ & $\begin{array}{l}\text { Yr2, Yr3, Yr4, YrSD, YrSO, YrND and } \\
\text { YrA }\end{array}$ \\
\hline 106 E139 A- Yr33+ & 1988 & - & $\begin{array}{c}1 \\
(2012)\end{array}$ & $\begin{array}{l}\text { Yr2, Yr3, Yr4, Yr7, YrSD, YrSO, YrND } \\
\text { and Yr33 }\end{array}$ \\
\hline $110 \mathrm{E} 143 \mathrm{~A}+$ & 1989 & 1986 & $\begin{array}{c}1 \\
(1993)\end{array}$ & $\begin{array}{l}\text { Yr2, Yr3, Yr4, Yr6, Yr7, Yr25, YrSD, } \\
\text { YrSO, YrND and YrA }\end{array}$ \\
\hline 111 E143 A- & 1988 & 2002 & $\begin{array}{c}1 \\
(1998)\end{array}$ & $\begin{array}{l}\text { Yr1, Yr2, Yr3, Yr4, Yr6, Yr7, Yr25, } \\
\text { YrSD, YrSO and YrND }\end{array}$ \\
\hline 234 E139 A+ Yr27+ & 1998 & - & $\begin{array}{c}1 \\
(1999)\end{array}$ & $\begin{array}{l}Y r 2, Y r 3, Y r 4, Y r 7, \operatorname{Yr} 9, \operatorname{YrSD}, \operatorname{YrSO}, \\
\operatorname{YrND}, \operatorname{Yr} A \text { and } Y r 27\end{array}$ \\
\hline 238 E 143 A- & 2003 & - & $\begin{array}{c}1 \\
(1998)\end{array}$ & $\begin{array}{l}Y r 2, Y r 3, Y r 4, Y r 6, Y r 7, Y r 9, Y r S D \\
Y r S O \text { and } Y r N D\end{array}$ \\
\hline 108 E141 A- & 1987 & 1983 & $\begin{array}{c}1 \\
(2015) \\
\end{array}$ & $\begin{array}{l}\text { Yr2, Yr3, Yr4, Yr6, Yr7, YrSD, YrSO } \\
\text { and YrND }\end{array}$ \\
\hline \multicolumn{5}{|l|}{ 'WA' pathotype } \\
\hline $134 \mathrm{E} 16 \mathrm{~A}+\mathrm{J}+$ & 2015 & 2007 & $\begin{array}{c}4 \\
(2011-2014)\end{array}$ & $\begin{array}{l}\text { Yr2, Yr6, Yr7, Yr8, Yr9, Yr25, YrA and } \\
\text { YrJ }\end{array}$ \\
\hline $134 \mathrm{E} 17 \mathrm{~A}+\mathrm{J}+$ & Present study & - & $\begin{array}{c}5 \\
(2012-2015)\end{array}$ & $\begin{array}{l}\text { Yr2, Yr4, Yr6, Yr7, Yr8, Yr9, Yr25, YrA } \\
\text { and YrJ }\end{array}$ \\
\hline $150 \mathrm{E} 16 \mathrm{~A}+\mathrm{J}+$ & Present study & 2005 & $\begin{array}{c}2 \\
(2012-2014) \\
\end{array}$ & $\begin{array}{l}\text { Yr2, Yr6, Yr7, Yr8, Yr9, Yr10, Yr25, } \\
\text { YrA and YrJ }\end{array}$ \\
\hline \multicolumn{5}{|l|}{ Unknown pathotype } \\
\hline 65 E17 A- & Present study & - & $\begin{array}{c}1 \\
(2014)\end{array}$ & Yr1, Yr4, Yr25 and $Y r S 92 / O$ \\
\hline
\end{tabular}

Five pathotypes were identified from samples collected from 2012 to 2015. Pathotype 108 E141 A- (Table 4) was from a sample collected in Canterbury in 2015, confirming the continued presence of this pathotype 28 years after its first detection (Wellings \& McIntosh 1990). In the current survey, the 'WA' Pst pathotype 134 E16 $\mathrm{A}+$ and its variants were the most commonly identified group (54\% of samples). Pathotype 134 $\mathrm{E} 16 \mathrm{~A}+\mathrm{J}+$, which is virulent to host resistance genes Yr2, Yr6, Yr7, Yr8, Yr9, Yr25, YrA, and YrJ, was identified in six samples collected between 2011 and 2014. This pathotype was found on many wheat varieties, including 'Sage', 'Morph', 'Einstein' and 'Tiritea', indicating it is now well established in Canterbury. Pathotype 134 E16
A+ J+ was first detected in Australia in 2007, with virulence for $\mathrm{YrJ}$, a rye-derived resistance gene found in some triticale varieties. Pathotype $134 \mathrm{E} 17 \mathrm{~A}+\mathrm{J}+$, an independent mutation of pathotype $134 \mathrm{E} 16 \mathrm{~A}+\mathrm{J}+$, with virulence for $\mathrm{Yr} 4$, was identified in samples collected from 201215. Pathotype 150 E16 A+ J+, also a variant of the 'WA' pathotype, has additional virulence for Yr10, and was identified in two samples collected from variety 'Sage' in 2012 and 2014. A rare pathotype $65 \mathrm{E} 17 \mathrm{~A}$-, identified from one sample collected in 2014, is virulent to Yr1, Yr4, Yr8, Yr25, and YrS92/O. These are the first detections of Pst pathotypes $134 \mathrm{E} 17 \mathrm{~A}+\mathrm{J}+, 150 \mathrm{E} 16 \mathrm{~A}+\mathrm{J}+$, and 65 E17 A- in New Zealand. 


\section{Leaf rust of wheat}

Of 23 viable leaf rust samples applied to differential sets, nine $P t$ pathotypes were identified (Table 5). These were the first New Zealand detections for eight of the nine leaf rust pathotypes. Pathotype 76-1,3,10,12, identified in a sample from the Manawatu-Wanganui region in 1989, was previously identified in samples sent to Australia from New Zealand in 1988. This pathotype is not related to the other eight pathotypes identified in the present study (Table 5). Pathotype 53-1,3,(6),(7),9,10,12 +Lr37, virulent to $L r 20, \quad L r 14 a, L r 27+L r 31$ (partial), Lr17a (partial), Lr26, Lr13, Lr17b and Lr37, was from leaf samples collected in 2015 from the Canterbury region. This is the first detection of this pathotype in New Zealand. Two pathotypes, 104-1,3,4,6,7,9,10,12+Lr37 and 104$1,3,4,6,7,8,9,10,12+\operatorname{Lr} 37$, believed to be closely related, comprised the most commonly identified Pt pathotype group in this survey. Pathotype $104-1,3,4,6,7,9,10,12+\operatorname{Lr} 37$ was isolated from leaf samples collected in 2012 and 2014 from the Manawatu-Wanganui and Canterbury regions, and is virulent to resistance genes $\operatorname{Lr} 20, \operatorname{Lr} 14 a$, Lr15, Lr27+Lr31,Lr17a,Lr26,Lr13,Lr17b and Lr37. Pathotype 104-1,3,4,6,7,8,9,10,12 +Lr37, identified from one sample collected in 2014, has additional virulence to $L r 28$. Pathotype 76-3,5,7,9,10,12,13 + Lr37 (virulent to $\operatorname{Lr} 14 a$, Lr3ka, Lr17a, Lr26, Lr13, Lr17b, Lr24 and Lr37) and pathotype $76-1,3,5,7,9,10,12,13+\operatorname{Lr} 37$ (additional virulence to $\operatorname{Lr} 20$ ) were the only pathotypes collected from the wheat varieties 'Empress' and 'Torch' in the 2014-15 season. Both varieties were known previously to have moderate resistance to leaf rust, but have recently shown a breakdown in resistance in the field. A single sample, collected in 2012 from the Manawatu-Wanganui region, was identified as $10-1,3,(7), 9,10,12$, which is a first record for New Zealand. This pathotype is virulent to $\operatorname{Lr} 2 a, \operatorname{Lr} 20$, Lr14a, Lr17a (partial) Lr26, Lr13 and Lr17b. Two pathotypes that could not be assigned an

Table 5 Pathotypes of Puccinia triticina (wheat leaf rust) identified in the present survey, their occurrence in New Zealand and Australia, and their virulence status to different resistance genes.

\begin{tabular}{|c|c|c|c|c|}
\hline Pathotype & $\begin{array}{l}\text { Year of first } \\
\text { New Zealand } \\
\text { detection }\end{array}$ & $\begin{array}{l}\text { Year of first } \\
\text { Australian } \\
\text { detection }\end{array}$ & $\begin{array}{l}\text { Number } \\
\text { of samples } \\
\text { (year of } \\
\text { collection) }\end{array}$ & Virulence to resistance genes \\
\hline $\begin{array}{l}\text { 53-1,3,(6),(7),9,10,12 } \\
+\operatorname{Lr} 37\end{array}$ & Present study & - & $\begin{array}{c}4 \\
(2015)\end{array}$ & $\begin{array}{l}\text { Lr20, Lr14a, Lr27, Lr31 (partial), } \\
\text { Lr17a (partial), Lr26, Lr13, Lr17b } \\
\text { and Lr37 }\end{array}$ \\
\hline $\begin{array}{l}104-1,3,4,6,7,9,10,12 \\
+\operatorname{Lr} 37\end{array}$ & Present study & - & $\begin{array}{c}6 \\
(2012-2014)\end{array}$ & $\begin{array}{l}\operatorname{Lr} 20, \operatorname{Lr} 14 a, \operatorname{Lr} 15, \operatorname{Lr} 27, \operatorname{Lr} 31, \operatorname{Lr} 17 a, \\
\operatorname{Lr} 26, \operatorname{Lr} 13, \operatorname{Lr} 17 b \text { and } \operatorname{Lr} 37\end{array}$ \\
\hline $\begin{array}{l}104-, 3,4,6,7,8,9,10,12 \\
+\operatorname{Lr} 37\end{array}$ & Present study & 2014 & $\begin{array}{c}2 \\
(2014)\end{array}$ & $\begin{array}{l}\operatorname{Lr} 20, \operatorname{Lr} 14 a, \operatorname{Lr} 15, \operatorname{Lr} 27, \operatorname{Lr} 31, \operatorname{Lr} 17 a, \\
\operatorname{Lr} 26, \operatorname{Lr} 13, \operatorname{Lr} 17 b, \operatorname{Lr} 37 \text { and } \operatorname{Lr} 28\end{array}$ \\
\hline $76-1,3,10,12$ & 1988 & & $\begin{array}{c}1 \\
(1989)\end{array}$ & Lr20, Lr14a, Lr3ka, Lr13 and Lr17b \\
\hline $\begin{array}{l}76-3,5,7,9,10,12,13 \\
+\operatorname{Lr} 37\end{array}$ & Present study & 2013 & $\begin{array}{c}2 \\
(2014)\end{array}$ & $\begin{array}{l}\text { Lr20, Lr14a, Lr3ka, Lr17a, Lr26, } \\
\text { Lr13, LrH, Lr17b, Lr24 and Lr37 }\end{array}$ \\
\hline $\begin{array}{l}76-1,3,5,7,9,10,12,13 \\
+\operatorname{Lr} 37\end{array}$ & Present study & 2014 & $\begin{array}{c}1 \\
(2014)\end{array}$ & $\begin{array}{l}\text { Lr14a, Lr3ka, Lr17a, Lr26, Lr13, } \\
\text { LrH, Lr17b, Lr24, Lr37and }\end{array}$ \\
\hline $10-1,3,(7), 9,10,12$ & Present study & 2004 & $\begin{array}{c}1 \\
(2012)\end{array}$ & $\begin{array}{l}\operatorname{Lr} 2 a, \operatorname{Lr} 20, \operatorname{Lr} 14 a, \operatorname{Lr} 17 a(\text { partial) } \\
\operatorname{Lr} 26, \operatorname{Lr} 13 \text { and } \operatorname{Lr} 17 b\end{array}$ \\
\hline$? ?-3,4,7,9,10,12$ & Present study & - & $\begin{array}{c}6 \\
(2014)\end{array}$ & $\begin{array}{l}\operatorname{Lr} 14 a, \operatorname{Lr} 15, \operatorname{Lr} 17 a, \operatorname{Lr} 26, \operatorname{Lr} 13 \text { and } \\
\operatorname{Lr17b}\end{array}$ \\
\hline$? ?-1,3,(7), 9,10,12$ & Present study & - & $\begin{array}{c}2 \\
(2014)\end{array}$ & $\begin{array}{l}\text { Lr20, Lr14a, Lr17a (partial), Lr26, } \\
\text { Lr13 and Lr17b }\end{array}$ \\
\hline
\end{tabular}


International Race number, viz. ??-3,4,7,9,10,12 (virulent to $L r 14 a, L r 15, L r 17 a, L r 26, L r 13$, and $L r 17 b$ ), and ??-1,3,(7),9,10,12 (avirulent to Lr15, partial virulence to $\operatorname{Lr} 17 a$, and additional virulence to $L r 20$ ), detected in samples collected from Canterbury and Manawatu-Wanganui in 2014-15, belong to the same pathotype group as Pt $10-1,3,(7), 9,10,12$. Neither pathotype ??$3,4,7,9,10,12$ nor ??-1,3,(7),9,10,12 is present in Australia.

\section{Leaf rust of barley}

Two pathotypes of $P h, 5457 \mathrm{P}$ - and $5457 \mathrm{P}+$, were identified from 10 samples (Table 6). Pathotype 5457 P-, identified in eight samples collected between 1999 and 2015, has virulence to the resistance genes $R p h 1, R p h 2, R p h 3, R p h 4, R p h 6$, Rph9, Rph10, Rph12, RphQ and RphC. Pathotype $5457 \mathrm{P}+$, detected in samples collected in 1989 and 2014, has additional virulence to Rph19 and Rph21.

Table 6 Pathotypes of Puccinia hordei (barley leaf rust) identified in the present survey, their occurrence in New Zealand and Australia, and their virulence status to different resistance genes.

\begin{tabular}{lcccl}
\hline Pathotype & $\begin{array}{c}\text { Year of first } \\
\text { New Zealand } \\
\text { detection }\end{array}$ & $\begin{array}{c}\text { Year of first } \\
\text { Australian } \\
\text { detection }\end{array}$ & $\begin{array}{c}\text { Number of } \\
\text { samples (year of } \\
\text { collection) }\end{array}$ & Virulence to resistance genes \\
\hline $5457 \mathrm{P}-$ & Present study & 2013 & $\begin{array}{c}7 \\
(1999-2015)\end{array}$ & $\begin{array}{l}\text { Rph1, Rph2, Rph3, Rph4, Rph6, } \\
\text { Rph8, Rph9, Rph10, Rph12, RphQ } \\
\text { and RphC }\end{array}$ \\
$5457 \mathrm{P+}$ & Present study ${ }^{\mathrm{A}}$ & 2008 & $2(1989-2014)$ & $\begin{array}{l}\text { Rph1, Rph2, Rph3, Rph4, Rph6, } \\
\text { Rph8, Rph9, Rph10, Rph12, Rph19, } \\
\text { Rph21, RphQ and RphC }\end{array}$ \\
\hline
\end{tabular}

${ }^{\mathrm{A} S i m i l a r}$ pathotypes were identified in the present study and that of Cromey and Viljanen-Rollinson (1995)

\section{DISCUSSION}

Information gathered through pathotyping surveys on the emergence of new rust pathotypes, and their associated virulence to resistance genes, is vital for timely disease management, appropriate cereal breeding strategies and providing growers with advance warning of new pathotypes before they cause significant economic damage.

New Zealand and Australia form an epidemiological unit by which rust pathotypes migrate between the two countries, either via wind currents or through other means, such as human movement. Closely related pathotypes derived by sequential step-wise mutations from a common ancestor can be seen in several pathotype lineages found in both countries (Steele et al. 2001; Wellings 2007). Monitoring the exchange and relatedness of rust pathotypes between New Zealand and Australia can provide valuable insights into the dispersal pathways of rusts entering Australasia, and safeguard the New Zealand cereal industry. For instance, the exotic wheat stem rust (caused by Puccinia graminis f. sp. tritici) 'Ug99' (first identified in Uganda in 1999) and barley stripe rust (caused by $P$. striiformis f. sp. hordei), are two rusts likely to cause major problems for the cereal industry if they were to reach either country. Two new Pst pathotypes, known as the 'Warrior' and 'Kranich' races, were identified in the United Kingdom in 2011. These cause increased disease on adult plants of wheat varieties carrying long-term effective adult plant-resistance genes (Hovmøller et al. 2016).

The present survey identified several pathotypes that had not previously been recorded in New Zealand. Eight $P t$ pathotypes identified were not recorded in New Zealand before 2002, and could have arrived either from Australia or from other parts of the world by wind or other means. At least two of the eight pathotypes are postulated to have spread to Australia from New Zealand, while two appear 
to have entered New Zealand from Australia. Pathotypes 76-3,5,7,9,10,12,13 + Lr37 and 76$1,3,5,7,9,10,12,13+\operatorname{Lr} 37$ were respectively detected in Australia in 2013 and 2014 (Park 2015). Both are mutational derivatives of a pathotype first recorded in Australia in 2004, which is of exotic origin. Both pathotypes arrived in New Zealand from Australia, most probably carried by the dominating westerly wind direction. Both pathotypes are virulent to $L r 24$, and they represent the first detection of virulence for this gene in New Zealand. This explains the breakdown of resistance to leaf rust in the wheat varieties 'Empress' and 'Torch'. Based on the pathotyping results, 'Empress' and 'Torch' are postulated to carry Lr24. The occurrence of virulence to Lr24 in New Zealand is significant, as this gene has been an important source of leaf rust resistance in New Zealand wheat breeding since the early 1980s. However, until pathotypes 76-3,5,7,9,10,12,13+Lr37 and $76-1,3,5,7,9,10,12,13+\operatorname{Lr} 37$ become widely distributed, Lr24 may still provide some level of disease control in New Zealand.

The origin of Pt 53-1,3,(6),(7),9,10,12 + Lr37 is unknown as it has not been detected in Australia. The most likely explanation is that it originated from 53-1,(6),(7),10,11, which was first detected in New Zealand in 1980 (Park \& Wellings 1992) and was subsequently found in Australia in 1984. If this is the case, it would have involved four mutational changes to its virulence in New Zealand, including to the host genes Lr14a, Lr17b, Lr26 and Lr37.

The detection of pathotype 104$1,3,4,6,7,9,10,12+\operatorname{Lr} 37$ from samples collected in 2012 suggests that it gave rise to the pathotype $104-1,3,4,6,7,8,9,10,12+\operatorname{Lr} 37$, identified from a 2014 sample, gaining virulence for $\operatorname{Lr} 28$. Pathotype 104-1,3,4,6,7,8,9,10,12 + Lr37 was first detected in Australia in 2014 and is likely to be an exotic introduction (Park, unpublished). This indicates that the pathotype likely migrated to Australia from New Zealand. This pathotype was found on the wheat variety 'Viceroy', which was moderately resistant to leaf rust before 2012, but has now become moderately susceptible to the disease. The results from the pathotyping suggest that 'Viceroy' carries the resistance gene Lr17a.

Pathotype $10-1,3,(7), 9,10,12$, which is a first record for New Zealand, was detected in Australia in 2004 and is locally known as the 'Mackellar' pathotype, an exotic introduction into Australia (Park 2015). This pathotype belongs to a group that includes pathotypes ??-3,4,7,9,10,12 and ??-1,3,(7),9,10,12, neither of which have been detected in Australia. One of the most striking features of all three pathotypes is that they are avirulent on the wheat variety 'Morocco'. This variety is used by rust researchers around the world because of its high susceptibility to wheat stripe, leaf, and stem rusts. Avirulence for the leaf rust resistance in 'Morocco' is considered to be very rare. Park et al. (2014) mapped the resistance gene carried by 'Morocco' and designated it Lr73, and is of no use in resistance breeding because of the widespread susceptibility to it. Exactly how the two pathotypes detected in New Zealand relate to the pathotype detected in Australia in 2004 is not straightforward. A simple explanation involves the assumed occurrence of a hypothetical pathotype ??-3,(7),9,10,12, which arrived in New Zealand, acquired virulence to genes $L r 1, L r 17 b$ and $\operatorname{Lr} 15$ over time, and developed its derivative ??-3,4,7,9,10,12. The pathotype also acquired virulence to $\operatorname{Lr} 20, \operatorname{Lr} 1$ and $L r 2 a$ to become the 'Mackellar' pathotype 10-1,3,(7),9,10,12. The 'Mackellar' pathotype then likely spread to Australia sometime before 2004.

The 'WA' Pst pathotype (134 E16 A+) is likely to have arrived in New Zealand from Australia through windborne dispersal, with further evolution occurring in New Zealand. This pathotype and its variants (pathotypes 134 E16 $\mathrm{A}+\mathrm{J}+, 134 \mathrm{E} 17 \mathrm{~A}+\mathrm{J}+$ and $150 \mathrm{E} 16 \mathrm{~A}+\mathrm{J}+$ ) are now well established in New Zealand. Pathotype 134 E16 A+ J+ was first detected in Australia in 2007, with virulence for $\mathrm{YrJ}$, a rye-derived resistance gene found in some triticale varieties. This explains the increased susceptibility of rye and triticale varieties such as 'Jackie' and 'Breakwell' to stripe rust in New Zealand. Virulence to $\operatorname{Yr} 10$ in the 'WA' pathotype lineage has previously been 
detected in Australia, although the pathotype (150 E16 A+) was found in only one location, and only in 2005. The original Pst pathotype (104 E137 A+) including the six variants within this pathotype lineage were common in New Zealand, but their prevalence has declined. These six pathotypes are likely to have developed sequentially through step-wise mutation of the original Pst pathotype 104 E137 A-, which was first recorded in New Zealand in 1980 (Beresford 1982). This was the first New Zealand detection of Pst pathotype 65 E17 A-, and it has never been detected in Australia. The pathotype may have been introduced to New Zealand from elsewhere around the world, or either pathotype $64 \mathrm{E} 0 \mathrm{~A}$ - or 64 E1 A- (detected in Australia in 1998) may have been introduced to New Zealand from Australia after 1998 (Cuddy 2016), and gained virulence to $\mathrm{Yr} 1$. Overall, there has been a decline in the incidence of Pst in New Zealand in recent years, which may be due to recent mild winters (NIWA 2018).

This survey identified only two $P h$ pathotypes, 5457 P+ or P-. Puccinia hordei cultures with the same pathotype designation exist in Australia (Park 2013) but subtle differences between the New Zealand cultures (identified as $5457 \mathrm{P}+$ ) and those found in Australia suggest that they are genetically different. The presence of only two $P h$ pathotypes from samples collected over 27 years suggests that this pathogen has low genetic diversity in New Zealand. In comparison, Cromey and Viljanen-Rollinson (1995) identified four pathotypes of $P h$ from 187 samples collected from 1990-93. One pathotype, 4657, is very similar to the pathotypes reported here, and is likely to be the same as $5457 \mathrm{P}+$. The difference in the two pathotype codes (viz. $5457 \mathrm{P}+$ and 4657) may be because Cromey and Viljanen-Rollinson (1995) were unable to assess virulence on Rph10 (code 1000) and Rph19 ("P+"), or to a difference in scoring of the Rph 8 differential 'Egypt' in the two studies. All $P h$ samples pathotyped in the present study were collected from the Canterbury region, as leaf rust is rare in North Island and Southland barley crops.

To generate accurate data, and ensure successful pathotype surveillance, it is critical that collaborations that develop and build on existing pathotyping expertise are maintained. These collaborations are particularly important for the Australasian region, but are also significant for world cereal cultivation and disease management.

\section{ACKNOWLEDGEMENTS}

This work was supported by the Plant \& Food Research Strategic Investment Fund, The Foundation for Arable Research, the Plant Biosecurity Cooperative Research Centre, and the Grains Research and Development Corporation. The contribution of cereal growers providing samples, and the co-ordination of FAR in sample collection is gratefully acknowledged.

\section{REFERENCES}

Beresford RM 1982. Stripe rust (Puccinia striiformis), a new disease of wheat in New Zealand. Cereal Rusts Bulletin 10: 35-41.

Braithwaite M, Cromey MG, Saville DJ, Cookson $\mathrm{T}$ 1998. Effects of fungicide rates and timing on control of stripe rust in wheat. Proceedings of the 51st New Zealand Plant Protection Conference, Quality Hotel, Hamilton, New Zealand, 11-13 August, 1998: 66-70.

Cromey MG 1992. A new pathotype of Puccinia striiformis in New Zealand with increased pathogenicity to wheat cultivars with the adult plant resistance gene Yr14. Australasian Plant Pathology 21: 172-174.

Cromey MG 2013. New lineage of stripe rust is virulent on triticale. In: From the Ground Up, Templeton. The Foundation for Arable Research. Pp. 9.

Cromey MG, Viljanen-Rollinson SLH 1995. Virulence of Puccinia hordei on barley in New Zealand from 1990 to 1993. New Zealand Journal of Crop and Horticultural Science 23: 115-119.

Cuddy W 2016. The wheat stripe rust pathogen in Australia - pathogenic variation and pathotype designation. https://rustbust.com. au/wp-content/uploads/2013/10/CerealRust-Report-2016-Vol-14-Issue-2.pdf (January 2018). 
Doling DA, Doodson JK 1968. The effect of yellow rust on the yield of spring and winter wheat. Transactions of the Bristish Mycological Society 51: 427.

Hovmøller MS, Walter S, Bayles RA, Hubbard A, Flath K, Sommerfeldt N, Leconte M, Czembor P, Rodriguez-Algaba J, Thach T, Hansen JG, Lassen P, Justesen AF, Ali S, Vallavieille-Pope C 2016. Replacement of the European wheat yellow rust population by new races from the centre of diversity in the near-Himalayan region. Plant Pathology 65: 402-411.

Huerta-Espino J, Singh RP, German S, McCallum BD, Park RF, Chen WQ, Bhardwaj SC, Goyeau H 2011. Global status of wheat leaf rust caused by Puccinia triticina. Euphytica 179: 143-160.

McIntosh RA, Wellings CR, Park RF 1995. Wheat rusts: an atlas of resistance genes. CSIRO Publishing, Melbourne, Australia.

Murray GM, Ellison PJ, Watson A 1995. Effects of stripe rust on the wheat plant. Australasian Plant Pathology 24: 261-270.

National Institute of Water and Atomospheric Research 2018. Seasonal Climate Summaries. https://www.niwa.co.nz/climate/summaries/ seasonal (April 2018).

Park RF 2013. Cereal rust report season 2013. New barley leaf rust pathotype detected in Western Australia. The University of Sydney, Plant Breeding Institute, Cobbity.

Park RF 2015. Long term surveys of pathogen populations underpin sustained control of the rust diseases of wheat in Australia. Journal and Proceedings of the Royal Society of New South Wales 148: 15-27.

Park RF, Wellings CR 1992. Pathogenic specialisation of wheat rusts in Australia and New Zealand in 1988 and 1989. Australasian Plant Pathology 21: 61-69.

Park RF, Mohler V, Nazari K, Singh D 2014. Characterisation and mapping of gene Lr73 conferring seedling resistance to Puccinia triticina in common wheat. Theoretical and Applied Genetics 127: 2041-2049.

Samborski D 1985. Wheat leaf rust. In: Roelfs AP, Bushnell WR eds. The Cereal Rusts.
Academic Press, Florida, USA. Pp. 39-59.

Steele KA, Humphreys E, Wellings CR,

Dickinson MJ 2001. Support for a stepwise mutation model for pathogen evolution in Australasian Puccinia striiformis f. sp. tritici by use of molecular markers. Plant Pathology 50: 174-180.

Wellings CR, McIntosh RA 1990. Puccinia striiformis f. sp. tritici in Australasia pathogenic changes during the first 10 years. Plant Pathology 39: 316-325.

Wellings CR, Wright DG, Keiper F, Loughman $R$ 2003. First detection of wheat stripe rust in Western Australia: evidence for a foreign incursion. Australasian Plant Pathology 32: 321-322.

Wellings CR 2007. Puccinia striiformis in Australia: a review of the incursion, evolution, and adaptation of stripe rust in the period 1976-2006. Australian Journal of Agricultural Research 58: 567-575. 